\title{
ASSOCIAÇÃO ENTRE O NÍVEL DE EVIDENCIAÇÃO DOS ATIVOS INTANGÍVEIS E O DESEMPENHO ECONÔMICO. FINANCEIRO DOS CLUBES DE FUTEBOL BRASILEIROS
}

\author{
Association between the level of disclosure of intangible assets and the \\ economic-financial performance of brazilian soccer clubs
}

Juliane Pacheco

E-mail: pac.juliane@gmail.com

Mestre em Contabilidade pelo Programa de Pós-graduação em Contabilidade da Universidade Federal de Santa Catarina; Doutoranda em Contabilidade no Programa de Pós-graduação em Contabilidade da Universidade Federal de Santa Catarina.

Endereço para contato: Rua Geraldo Jansen, 75, Ponte do Imaruim, 88130-425, Palhoça, Santa

Catarina, Brasil.

https://orcid.org/0000-0001-6138-4835

Maíra Melo de Souza

E-mail: mairameloufsc@gmail.com

Doutora em Administração pelo Programa de Pós-graduação em Administração da Universidade Federal de Santa Catarina; Mestre em Contabilidade pela Universidade Federal de Santa Catarina;

Professora Adjunta no Departamento de Ciências Contábeis da Universidade Federal de Santa

Catarina.

https://orcid.org/0000-0002-9237-1348 


\section{Resumo}

O objetivo desta pesquisa é verificar a associação entre o nível de evidenciação dos ativos intangíveis e o desempenho econômico financeiro dos clubes de futebol brasileiros. A amostra da pesquisa são os clubes que participaram do Campeonato Brasileiro das Séries $\mathrm{A}$ e $\mathrm{B}$ de 2017, visto que foram analisados os anos de 2013 a 2016. Para medir o nível de evidenciação, utilizou-se a norma em vigência ITG $2003 \mathrm{Rl}$, e para medir o desempenho econômico-financeiro foram utilizadas seis variáveis: receita líquida, resultado líquido do exercício, patrimônio líquido, ativo intangível, ativo total e intangibilidade. Adicionalmente, também se analisou a variável auditoria. Com relação aos resultados da pesquisa, apenas o resultado líquido e o ativo intangível estão associados ao nível de evidenciação. Concluiuse também que os clubes são parcialmente transparentes, em razão de metade da amostra apresentar um nível de evidenciação acima da média (cerca de 60\%), o que sugere que entre os clubes analisados é preciso ser mais abrangente na evidenciação das informações para se adaptar completamente à norma de contabilidade.

Palavras-chave: Clube de futebol. Evidenciação contábil. Ativo intangível.

\section{Abstract}

The objective of this research is to verify the association between the level of disclosure of intangible assets and the financial economic performance of Brazilian soccer clubs. The research sample is the clubs that participated in the Brazilian Championship in the $A$ and $B$ Series of 2017, the years 2013 to 2016 were analyzed. To measure the level of disclosure, the standard in force was used, ITG $2003 \mathrm{Rl}$, and to measure financial economic performance, six variables: net revenue, net income, net equity, intangible assets, total assets and intangibility. In addition, the audit variable was also analyzed. In relation to the results of the research, only the net result and the intangible asset are positively associated with the level of disclosure. It was also concluded that the clubs are partially transparent, because just over half of the sample has an above-average level of disclosure (about 60\%), which suggests that in the analyzed clubs it is necessary to be more comprehensive in the disclosure of information to suit completely the accounting standard.

Keywords: Soccer team. Accounting disclosure. Intangible assets.

\section{INTRODUÇÃO}

Em meados de 1894, Charles W. Miller voltou da Inglaterra com a bola do esporte que atualmente inspira milhões de brasileiros, o futebol, porém há contradições sobre o início do esporte no Brasil (Gambeta, 2013). Apesar de no início ser um esporte aristocrata, posteriormente passou a ser admirado também pelas classes mais baixas, em razão de que nos fins de semana havia reuniões de proletariados e estudantes para jogar futebol (Rondinelli, 2015) Com os anos o futebol deixou de ser um hobby para virar um negócio profissionalizado. Os clubes começaram a cobrar a entrada dos jogos, o comércio de produtos licenciados e o marketing cooperaram para a arrecadação de receitas (Costa \& Silva, 2006).

Em 2007 a receita anual de 21 clubes de futebol totalizou R \$ 1,34 bilhões de reais, entretanto, apenas seis clubes apresentaram lucro no exercício (Romão \& Castellar, 2008). Dahlbäck e Lind (2016) relatam que de 1996 a 2014 a receita dos clubes de futebol europeu 
aumento $500 \%$, porém o lucro operacional é praticamente inexistente. Em decorrência dessa diferença entre altas receitas e poucos lucros, Russano e Marino (2007) destacaram que o problema financeiro dos clubes pode estar relacionado à gestão amadora, bem como o declínio do público no estádio às transmissões televisivas.

Conforme as receitas dos clubes de futebol foram aumentando, principalmente em decorrência das negociações de jogadores, o Estado passou a intervir na forma como os clubes eram dirigidos, e em 1998 foi criada a Lei Pelé (Lei 9.615) com a finalidade de dar maior transparência a essas negociações, inclusive no que compete à prestação de contas (Cordeiro, 2014; Costa \& Silva, 2006; Frey \& Zaia, 2014).

Apesar de a legislação ter se tornado mais intensa, as entidades desportivas não possuíam aspectos contábeis específicos, por isso, o Conselho Federal de Contabilidade (CFC), por meio da Resolução CFC 1.005 (2004), aprovou a norma brasileira NBC T 10.13. Essa norma trouxe grandes mudanças nas Demonstrações Contábeis, com novos critérios a fim de padronizar os registros contábeis de entidades desportivas, mudando, assim, sua evidenciação. Porém, a NBC T 10.13 foi revogada pela Resolução CFC 1.429 (2013) (atualizada em 2017), criando a Interpretação Técnica Geral 2003 Rl, que trata de Contabilidade de Entidades Desportivas Profissionais, trazendo mudanças significativas, principalmente no que diz respeito ao registro dos atletas, contabilizados agora no ativo intangível.

Conforme Bastos, Pereira, e Tostes (2007), o ativo intangível de um clube de futebol, na maioria, são as habilidades do atleta, além do uso de sua imagem. Com o crescimento dos direitos de imagem e dos valores dos passes, o intangível passou a ter uma atenção especial. $E$, nessa perspectiva, sua adequada evidenciação também ganha relevância, além de que se pode constatar a situação econômico-financeira e patrimonial de uma empresa por meio das demonstrações contábeis obrigatórias ou por outros tipos de relatório (Machado \& Nunes, 2006). Para Machado e Nunes (2006), a evidenciação, por meio das demonstrações contábeis obrigatórias ou dos mais variados tipos de relatórios emitidos, constata a situação econômico-financeira e patrimonial de uma empresa.

Chik (2017) relata que os ativos intangíveis dos clubes de futebol ucranianos vêm crescendo nos últimos anos e já representam de 15 a 20\% do ativo desses clubes. Nessa perspectiva de valor dos ativos intangíveis nos clubes de futebol, Cordeiro (2014), Costa e Silva (2006), Frey e Zaia (2014) e Romão e Castellar (2008) observaram em suas pesquisas o crescente aumento das receitas.

As mudanças ocorridas na legislação brasileira que trata dos times de futebol tornam a adequada evidenciação dos ativos intangíveis importante. Considerando ainda a relevância da evidenciação para a sociedade (investidores, torcedores, governo) sobre os atletas em formação e profissionais, visto que seus contratos envolvem valores altíssimos, elaborouse a seguinte pergunta de pesquisa: qual a associação entre o nível de evidenciação dos 
ativos intangíveis e o desempenho econômico-financeiro dos clubes de futebol brasileiros? O objetivo desta pesquisa é verificar a associação entre o nível de evidenciação dos ativos intangíveis e o desempenho econômico-financeiro dos clubes de futebol brasileiros.

Os clubes de futebol foram escolhidos para serem objeto de estudo em razão de ser um esporte com transações de alto valor, e expressivo mundialmente. Em adição a isso, a contabilidade e a legislação desportiva evoluíram desde o seu surgimento. Desse modo, é de grande relevância que a mensuração seja realizada de forma correta, bem como a divulgação das informações seja realizada de maneira adequada e completa, para que os usuários externos possam avaliar como está a gestão que comanda o clube, bem como as finanças e se as obrigações estão sendo sustentadas pela receita que os atletas proporcionam, seja ela derivada de patrocinadores, público em jogos, seja ainda de direitos televisivos.

O investimento no esporte, financeiro e social, coloca níveis mais altos de expectativa sobre aqueles que estão envolvidos dentro e fora do campo (Sherry, Shilbury, \& Wood, 2007). Nessa perspectiva, uma evidenciação de qualidade contribui para a confiabilidade das demonstrações contábeis, e estudar a evidenciação se faz necessário principalmente a partir de 2013, em que a harmonização com as normas internacionais das demonstrações contábeis das entidades desportivas foi abrangida pela ITG 2003 Rl. Além de que, estudos sobre a evidenciação do intangível contribuem para o entendimento da área, visto que os atletas profissionais são segregados dos demais, podendo contribuir com novos patrocinadores.

Os estudos anteriores focam na legislação revogada, e poucos associam sua evidenciação ao desempenho econômico-financeiro, além de alguns focarem nos clubes pertencentes ao Programa de Modernização da Gestão e de Responsabilidade Fiscal do Futebol Brasileiro (Profut), abordando períodos a partir de 2015, mas que também são regidos pela ITG 2003 R1. Destarte, o presente estudo busca estender a literatura sobre as entidades desportivas na área de contabilidade e a evidenciação dos seus intangíveis.

\section{REFERENCIAL TEÓRICO}

O presente referencial teórico está dividido em duas seções. Inicialmente, aborda-se - avanço das normas contábeis sobre as entidades desportivas, desde o Decreto-Lei 3.199 (1941) até a ITG $2003 \mathrm{RI}$, que classificou os atletas como ativos intangíveis dessas entidades; e sobre a importância da evidenciação contábil. A segunda seção aborda os estudos similares sobre a contabilidade das entidades desportivas. 


\subsection{EVIDENCIAÇÃO DOS ATIVOS INTANGÍVEIS PARA ENTIDADES DESPORTIVAS}

Em 1941 houve a criação, por meio do Decreto-Lei 3.199 (1941), do Conselho Nacional de Desportos (CND) e dos Conselhos Regionais de Desportos (CRDs), os quais estabelecem bases para as atividades desportivas do País. Apenas com a Lei n. 8.672 (1993), conhecida como Lei Zico, o Estado passou a interferir nos clubes desportivos, porém a legislação brasileira passou a ser mais presente na forma como os clubes eram regidos em 1998, com a promulgação da Lei Pelé (Lei 9.615, 1998), a qual trouxe a extinção do passe do atleta, contratos com cláusula penal, direito de imagem, seguro obrigatório, categorias profissionais e semiprofissionais. Uma das principais mudanças da Lei Zico para a Lei Pelé foi a transformação dos clubes em "clube-empresa", ou seja, agora as entidades desportivas não seriam mais "sem fins lucrativos", tendo, portanto, maiores responsabilidades com o comando que anteriormente pertencia aos investidores.

O caminhar da legislação desportiva tomou outro rumo em 2002, com a promulgação da Medida Provisória 39, posteriormente convertida na Lei 10.672 (2003), a qual tornou obrigatória a elaboração e publicação das demonstrações contábeis e assinalava que as demonstrações deveriam ser averiguadas por auditores independentes (Bastos et al., 2007; Holanda, Meneses, Mapurunga, De Luca, \& Coelho, 2012). Porém a Lei 10.672 (2003) não dispunha de normas específicas para elaboração, o que ocasionou na publicação da Resolução 1.005 (2004) pelo Conselho Federal de Contabilidade (CFC), que aprovou a NBC T 10.13, instituindo critérios a fim de padronizar as normas contábeis das entidades desportivas. Entre as determinações está o registro dos atletas no ativo imobilizado, além dos valores relacionados à formação de atleta em conta específica. Além disso, a Lei n. 11.638 (2007) e a Lei n. 11.941 (2009) trouxeram transparência e informação para os usuários das demonstrações financeiras das entidades desportivas.

Rezende, Salgado, Ribeiro, e Dalmacio (2008) identificaram, ao estudar 70 demonstrações contábeis de clubes brasileiros, no período de 2001 a 2007, que após a NBC T 10.13 houve uma grande aderência à norma. Porém, na análise feita por Rezende e Custódio (2012), observou-se que os clubes nacionais ainda não evidenciavam todos de forma igual, inexistindo, assim, uma possível comparação. Tratamentos diferentes para o custo dos atletas, os passes e contratos dos profissionais e semiprofissionais e a reavaliação dos esportistas foram identificados por Russano e Marino (2007), indicando a não adesão à norma contábil.

Já Oliveira, Bianchi, e Souza (2014) encontraram o custo de formação dos jogadores registrados no intangível, em vez de no imobilizado, como requerido na norma. Essa diferença é observada por Bastos et al. (2007), quando compararam a evidenciação dos clubes de 
futebol europeus com a dos brasileiros. Na Europa os atletas estavam evidenciados no subgrupo do intangível, enquanto no Brasil eram registrados no do imobilizado.

Com a harmonização das normas contábeis entre 2005 e 2010, as normas brasileiras passaram por diversas alterações, entre elas a criação do Pronunciamento Técnico CPC 04-Ativo Intangível, correlato à norma internacional International Accounting Standard 38 (IAS 38), que define ativo intangível como um ativo não monetário identificável sem substância física (Pronunciamento Técnico CPC 04 Rl, 2010). Zanotelli, Amaral, e Souza (2013) acreditam que os intangíveis não eram contabilizados corretamente, que muitas entidades preferiam evidenciar como despesa do período, e com a vinda da Lei 11.638 (2007), os ativos incorpóreos passaram a ser evidenciados em um subgrupo específico chamado de ativos intangíveis.

Ao assinar um contrato com uma entidade desportiva, o atleta se dispõe a prestar um serviço, ou seja, o clube desfruta das habilidades do atleta, além da imagem (Bastos et al., 2007). Como não é possível separar a habilidade ou a imagem do jogador, ele passa a configurar um ativo intangível para as entidades desportivas.

Quando o desempenho do grupo de atletas for bom, gera para a instituição benefícios, como, por exemplo, aumento da bilheteria e publicidade (Cruz, Santos, \& Azevedo, 2010), atendendo, assim, o quesito de ativo e, por conseguinte, de ativo intangível. A relação entre jogadores e intangível é similar à relação entre pesquisa e desenvolvimento, visto que, quando um jogador se torna profissional, esses custos são capitalizados ou alocados como despesa caso as habilidades desse atleta não alcancem os objetivos do clube (Mello, Gonçalves, Correia, \& Mourão, 2018), e são importantes em razão de possível geração de receitas pela sua venda.

Para harmonizar com a IAS 38, e assim com as normas internacionais, em janeiro de 2013 passou a vigorar a Resolução CFC 1.429, a qual determina a aplicação da ITG 2003, que resultou em critérios e procedimentos específicos na evidenciação contábil das entidades desportivas (Resolução 1.429, 2013). Entre as principais alterações, no intangível se reconhecem os atletas, os direitos de imagem e os gastos diretamente atrelados à sua formação. Com a vinda da ITG 2003, as entidades tiveram que se adaptar à norma a partir de 2013, reestruturando suas demonstrações. A interpretação, no seu item 17, contém informações que devem ser divulgadas pelas entidades, proporcionando uma harmonização, sendo, portanto, necessário verificar se os clubes estão aderindo à nova legislação.

Pela Lei 13.155 (2015) foi criado o PROFUT, com o objetivo de promover a gestão transparente e democrática, além do equilíbrio financeiro da entidade desportiva. Foi criada a Autoridade Pública de Governança do Futebol (Apfut), que dentro das suas finalidades está a fiscalização das entidades desportivas para que cumpram suas obrigações. Em 2017 a versão 1.1 do Manual da Contabilidade para Entidades Esportivas foi publicada pela Apfut 
e objetiva auxiliar as entidades desportivas com regras sobre as formas de contabilização, sendo uma maneira de boas práticas de gestão no dia a dia das entidades, dando maior credibilidade às demonstrações contábeis. Além disso, no intangível deverá ser segregado o custo de aquisição de atletas, custo de formação de atletas, custo de atletas formados e demais ativos intangíveis, respeitando os mesmos critérios da ITG 2003 Rl, tanto no reconhecimento quanto na mensuração. O fato de a Apfut coincidir com a ITG 2003 RI reforça que os clubes necessitam de transparência em suas demonstrações contábeis. Além disso, segundo ludícibus (2009), no Brasil a evidenciação é praticamente sinônimo de notas explicativas, mesmo existindo outros meios de informação complementar, como comentários de auditores ou quadros suplementares.

Hendriksen e Van Breda (1999) destacam que caso a evidenciação não seja adequada, justa e completa pode se tornar enganosa, visto que não se trata do que divulgar, mas a maneira mais eficiente. Ou seja, a informação precisa ser adequada para explicar os detalhamentos referentes ao valor que foi divulgado, e é necessário que represente o fenômeno que está sendo retratado, além disso, tem que ser completa com tudo que engloba o valor, tanto as deduções quanto as adições.

Verrecchia (1983), por meio da Teoria da Divulgação, salienta que a qualidade e a quantidade de informações divulgadas da entidade vão ao encontro do que o gestor deseja divulgar, nem sempre sendo neutro no que evidenciar. Dessa maneira, o gestor pode decidir com relação à qualidade e à quantidade da divulgação. Relacionando a Teoria da Divulgação com as demonstrações contábeis das entidades desportivas, tem-se a publicação voluntária da Demonstração do Valor Adicionado (DVA). Tanto a ITG 2003 R1 quanto o Manual de Contabilidade das Entidades Esportivas continuam deixando facultativo, entretanto, a DVA proporciona aos usuários informações de quanto o clube criou de riqueza no período, bem como sua transferência para terceiros (por exemplo, governo e atletas).

Por fim, as mudanças na legislação fizeram com que os atletas tivessem espaço nas demonstrações contábeis, e classificando-os como intangíveis, buscam a harmonização com outros países, por exemplo, as entidades desportivas da Europa. Dessa maneira, é preciso verificar a adesão das entidades desportivas à ITG 2003 Rl e como essa evidenciação, se relacionada com o desempenho econômico-financeiro, fornece indicativos sobre o comportamento dos clubes, sobre o que poderia indicar uma maior evidenciação dos seus intangíveis (atletas).

\subsection{ESTUDOS SIMILARES}

A busca pelo padrão e sua evidenciação nos clubes de futebol pesquisados anteriormente relata a falta de padrão e o baixo nível de evidenciação, como analisado por 
Dahlbäck e Lind (2016) na transparência das demonstrações contábeis dos clubes europeus em 2014 e 2015, visto que a Union of European Football Associations (UEFA) estabeleceu a Financial Fair Play (FFP) para que os clubes fossem mais financeiramente sustentáveis. Os resultados apontaram que a transparência está presente nas demonstrações contábeis, mesmo que limitada, entretanto, fatores como ser um clube listado na bolsa de valores ou que tenha alguma exigência externa para divulgação farão dele sempre mais transparente do que aqueles que não possuem essas exigências. Dessa forma, os autores concluem que os clubes europeus de futebol não são transparentes em seus demonstrativos contábeis.

Analisando a evidenciação das demonstrações contábeis dos 100 maiores clubes segundo o ranking da Confederação Brasileira de Futebol (CBF) nos anos de 2006 a 2009, Holanda et al. (2012) observaram uma baixa proporção de publicação das demonstrações (69 de 400). Sobre a formação dos atletas, os autores notaram que os custos foram explorados em notas explicativas, registrados como despesa do período, porém o nível de evidenciação aumentou no decorrer dos anos. Outra conclusão, por meio de testes estatísticos, foi que quanto maior a receita, maior o nível de evidenciação dos clubes de futebol.

Já Rezende e Custódio (2012) encontraram a falta de adesão da norma NBC T 10.13 nas demonstrações contábeis de 11 clubes do Campeonato Brasileiro da Série A de 2007, e apesar de estes apresentarem o valor do custo e amortização dos atletas, apenas dois divulgaram o prazo (Palmeiras e São Paulo). Entre os pesquisados, apenas o Santos relatou a reavaliação dos direitos sobre os atletas, o que gerou uma superavaliação no ativo, comprometendo a confiabilidade da informação.

Alves, Behr, e Raimundini (2012) identificaram as práticas de reconhecimento e evidenciação de ativos intangíveis no Grêmio, e encontraram que, apesar de este estar ciente da exigência da norma, não divulga em razão de estratégia de negócios, demonstrando pouco interesse em informar sobre suas práticas contábeis para registro do intangível.

$E$, por fim, em uma pesquisa mais recente e depois de sete anos de a NBC T 10.13 estar em vigor, Cordeiro (2014) analisou os 40 clubes do Campeonato Brasileiro das Séries $A$ e $B$ na expectativa de apontar que quanto maior o clube, maior o nível de evidenciação. Inicialmente, dos 40 clubes, apenas 27 divulgaram as demonstrações contábeis, e destes, ficou comprovado que os clubes com maior faturamento obtiveram o maior nível de informação.

Com base no vigor do Pronunciamento Técnico CPC 04 (2010), o estudo de Leite e Pinheiro (2014) fez um check-list com 34 itens, destacando como um dos itens mais evidenciados a distinção entre gerados internamente e outros intangíveis; em contrapartida, o teste de recuperabilidade foi pouco evidenciado. Os autores verificaram que o "desempenho no campeonato brasileiro" e as "receitas totais" influenciaram o nível de divulgação do ativo intangível, já a "representatividade do intangível" não foi significante, concluindo que quanto melhor o desempenho, mais atrai investidores, tendo, assim, transparência nas demonstrações contábeis. 
Já no estudo de Mota, Brandão, e Ponte (2016) o nível de disclosure mostrou-se correlacionado positivamente com a materialidade do intangível, assim como com o desempenho do clube, indicando um poder explicativo de $37,11 \%$, sugerindo que a informação divulgada está concernente ao quão relevante (material) é, senão passa a ser omitida. Já o nível de disclosure dos clubes da Série A do Campeonato Brasileiro de Futebol no período de 2010 a 2012 obteve uma média de 9 dos 27 itens analisados.

Analisando os clubes de futebol com base na ITG 2003 RI (Resolução CFC 1.429, 2013), Maia e Vasconcelos (2016) identificaram o perfil dos ativos intangíveis em 18 clubes brasileiros e 48 clubes europeus em 2011. Encontraram que 60 dos 66 clubes (16 são brasileiros) não evidenciam o número de atletas, e 43 clubes ( 7 brasileiros) não citam a aplicação do teste de recuperabilidade. Com relação à vida útil dos ativos, 32 clubes não evidenciaram, enquanto o método de amortização foi evidenciado por 39 clubes.

O estudo de Souza, Sousa, Nascimento, e Bernardes (2016) analisou a aderência da resolução na elaboração e evidenciação das Demonstrações Contábeis por 19 clubes brasileiros no ano de 2013. Os autores encontraram que $100 \%$ dos clubes evidenciam as demonstrações obrigatórias, exceto os resultados abrangentes, e a média de evidenciação é de $53,04 \%$. Quanto à formação dos atletas, $79 \%$ dos clubes apresentaram, já a amortização foi divulgada por $84 \%$, os gastos com formação foram atendidos por $63 \%$ dos clubes, o seguro foi evidenciado por $58 \%$, e, por fim, o total de atletas e o percentual de direito econômico foram evidenciados por apenas $21 \%$ da amostra.

Marques, Santos, Ferreira, Amaral, e Souza (2017) identificaram o nível de cumprimento de 56,38\% das exigências estabelecidas na Resolução CFC 1.429 (2013) por 16 clubes do futebol brasileiro integrantes da organização Clube dos Treze, durante o período amostral de 2007 a 2013. Além disso, indicou uma baixa divulgação dos gastos com formação do atleta segregado por tipo, e o total de atletas vinculados ao Clube. Constataram também que de 2007 a 2013 houve um aumento significativo de atendimento à norma, sendo que em 2013 apresentou o melhor nível de evidenciação, visto que foi o ano de adesão à norma.

Com relação ao direito de imagem, Farias e Teixeira (2019) verificaram os clubes pertencentes à série A do Campeonato Brasileiro de 2014 a 2016 e encontraram que após quatro anos da aprovação da norma, metade dos clubes ainda não evidenciavam corretamente os direitos de imagem, resultando na falta de transparência dos clubes.

Já o estudo de Figueiredo, Santos, e Cunha (2017) identificaram que a maioria dos clubes das Séries A e B de 2011 a 2015 apresentam suas demonstrações contábeis, porém não atendem a todas as obrigações, o que compromete a comparabilidade. Além disso, o gasto com a formação dos atletas e o valor amortizado foram amplamente divulgados, enquanto a média dos clubes da Série A foi de $61 \%$ e a dos da Série B foi de 35,2\%. Cabe ressaltar que os autores utilizaram a Resolução CFC 1.429 (2013) na elaboração do nível de evidenciação, 
entretanto, o período temporal analisado antecede a norma, o que compromete a análise em 2011 e 2012, não destacado pelos autores.

O estudo de Umbelino, Silva, Ponte, e Lima (2019) encontrou que o nível de disclosure esportivo com foco na assistência governamental (subvenção governamental), em razão do empréstimo concebido para parcelar os débitos fiscais decorrentes da adesão em 2015 e permanência em 2016 dos clubes ao PROFUT não melhorou, entretanto, o nível está atrelado ao desempenho econômico-financeiro (retorno sobre ativos-ROA, retorno sobre patrimônio líquido-ROE, tamanho e endividamento); já não houve essa relação ao desempenho esportivo (série, classificação no campeonato e média de pagantes).

O estudo de Dimitropoulos e Koumanakos (2015) apontou que existe uma associação positiva entre o capital intelectual e a lucratividade nos clubes de futebol de nove países europeus nos anos de 2005 a 2010, indicando que os jogadores mais caros tendem a acrescentar valor à organização acarretando um melhor desempenho financeiro.

No tocante aos clubes de futebol das Séries A, B e C, Silva, Santos, e Cunha (2017) verificaram que a alta participação de terceiros sobre os recursos totais, endividamento $e$ baixa liquidez imediata resultou em um parecer com ressalva, enquanto a baixa liquidez imediata, margem de lucro e tamanho, e o alto ROI, endividamento e participação de terceiros sobre os recursos totais estão relacionados com o relatório com ênfase. Já Benin, Diehl, e Figueira-Marquezan (2019) apontaram, ainda, que a maioria dos resultados financeiros foi negativa, o que deveria resultar em uma maior evidenciação de indicadores não financeiros, diminuindo a avaliação negativa de agentes externos, entretanto, a divulgação foi positivamente relacionada com a rentabilidade atual, contribuindo para a transparência do clube. Concluíram que o nível de divulgação não é impactado pelo desempenho do clube.

Percebe-se que os estudos não possuíram como foco específico o intangível, visto que alguns analisaram o período anterior à legislação e outro analisou apenas um ano e de maneira mais ampla, ou ainda um item específico. Além disso, alguns estudos que analisaram a ITG 2003 R1 exploraram as demonstrações anteriores a ela. Os resultados, de maneira geral, encontraram que o padrão proposto pela legislação anterior não ocorreu, e quando ocorreu, foi parcialmente, porém, a NBC T 10.13 que foi revogada. Assim, para uma maior padronização, a ITG 2003 Rl entrou em vigor, por isso se faz necessário analisar se os clubes estão ou não seguindo a padronização, utilizando um período temporal que vigora a legislação e expandindo a amostra para os clubes do Campeonato Brasileiro de Futebol das Séries A e B. Como diferencial, buscou-se verificar a relação entre a evidenciação e o desempenho econômico-financeiro, com o intuito de observar se as entidades desportivas com maior evidenciação tendem a ter um desempenho melhor (receita e resultado líquido). 


\section{PROCEDIMENTOS METODOLÓGICOS}

Esta seção está dividida em duas subseções: amostra da pesquisa e procedimentos de análise dos dados, sendo que a segunda está dividida em nível de evidenciação de acordo com a ITG 2003 Rl e o desempenho econômico-financeiro e modelo de regressão com dados em painel, com o escopo de verificar a associação entre o nível de evidenciação dos ativos intangíveis e o desempenho econômico-financeiro dos clubes de futebol brasileiros.

\subsection{AMOSTRA DA PESQUISA}

Como existe mais de 400 clubes de futebol no Brasil, foram considerados como base para análise, do período amostral de 2013 a 2016, os clubes que disputaram o Campeonato Brasileiro nas Séries A e B de 2017 (Confederação Brasileira de Futebol, 2017a; 2017b), visto que é o campeonato nacional mais importante, com times participantes de maior expressão do País e com maiores possibilidades de garantir vaga para competições internacionais, como Libertadores e Sul-americana.

Dessa forma, a população para análise foi composta pelas 160 demonstrações contábeis dos 40 clubes de futebol, coletadas nos sites oficiais dos respectivos clubes ou nos sites da Federação do Estado. Por exemplo, dos clubes de Santa Catarina foram coletadas no site da Federação Catarinense de Futebol, já do clube Sociedade Esportiva Palmeiras foram coletadas do seu site oficial. O período de coleta das demonstrações foi de 2 a 6 de fevereiro de 2018. Após esse levantamento, conforme demonstrado na Tabela 1, foram excluídas da amostra 41 demonstrações por não terem sido publicadas, restando 119 demonstrações a serem analisadas.

Tabela 1

População e exclusões da pesquisa

\begin{tabular}{lrrrrr}
\hline \multicolumn{1}{c}{ Amostra\Ano } & 2013 & 2014 & 2015 & 2016 & Total \\
\hline População & 40 & 40 & 40 & 40 & 160 \\
\hline (-) Não publicaram as demonstrações contábeis & 13 & 12 & 8 & 8 & 41 \\
\hline Amostra & 27 & 28 & 32 & 32 & 119 \\
\hline (-) Não apresentaram as notas explicativas & 2 & 3 & 6 & 4 & 15 \\
(-) Não possui intangível no balanço & - & 1 & 2 & 1 & 4 \\
(-) Não aderiu à ITG 2003 & 4 & 1 & 1 & 1 & 7 \\
\hline Amostra final & 21 & 23 & 23 & 26 & 93 \\
\hline
\end{tabular}

Entre as 41 demonstrações contábeis não apresentadas, 28 foram de clubes que não apresentaram as demonstrações contábeis em nenhum dos quatro anos analisados, são eles: 
$A B C$ Futebol Clube, Boa Esporte Clube, Clube de Regatas Brasil (CRB), Londrina Esporte Clube, Luverdense Esporte Clube, Paraná Clube e Oeste Futebol Clube.

Das 119 demonstrações analisadas, 15 foram excluídas por não apresentarem suas notas explicativas, o que distorceria o nível de evidenciação apresentado a seguir; quatro por não apresentarem intangível no balanço patrimonial e sete por não terem aderido à ITG 2003 R1 durante o período da amostra, o que resultou em uma amostra final de 93 demonstrações para análise, ou seja, 93 observações.

\subsection{PROCEDIMENTOS DE ANÁLISE DOS DADOS}

Para organização desta subseção, os procedimentos de análise dos dados apresentam as informações sobre a obtenção do nível de evidenciação e o desempenho econômicofinanceiro e modelo de regressão com dados em painel.

\subsubsection{Nível de Evidenciação}

A ITG 2003 Rl, com o objetivo de introduzir "critérios e procedimentos específicos de avaliação, de registros contábeis e de estruturação das demonstrações contábeis", (Resolução CFC 1.429 , 2013) estabeleceu mudança na legislação de forma a criar um padrão entre as entidades desportivas.

O nível de evidenciação, como no estudo de Souza et al. (2016), foi elaborado com base nos itens extraídos da ITG 2003 RI (Resolução CFC 1.429, 2013) e constam na Tabela 2, e foi calculado por meio de um índice com base na Equação 1. Para a análise da evidenciação foi adotada a seguinte metodologia: nos casos em que a respectiva informação constava nas notas explicativas ou nas próprias demonstrações contábeis do respectivo clube em análise, atribuiu-se 1 (um ponto) indicando "sim", presença da informação. Nos casos em que a informação foi encontrada de maneira parcial (incompleta), atribuiu-se 0,5 (meio ponto) indicando "informações parciais", e nos casos em que não houve a evidenciação da informação, atribuiu-se 0 (zero), indicando "não evidência". Nos casos em que a informação não se enquadrava no clube, foi atribuído "NA-não se aplica", excluindo o item da métrica.

Índice de evidenciação $=$

$\frac{\Gamma \text { item } \times 100}{\text { (Número de quesitos-não se aplica) }}$

Com relação à lista de verificação apresentada na Tabela 2, o primeiro item para avaliar se o clube está atendendo à norma é o fato de publicar suas demonstrações contábeis obrigatórias, sendo estas: balanço patrimonial, demonstração do resultado do exercício, 
demonstração do resultado abrangente, demonstração das mutações do patrimônio líquido, demonstração do fluxo de caixa e notas explicativas. Para esse item, caso algum clube tenha deixado de apresentar uma das demonstrações contábeis mencionadas, receberá 0,5.

Tabela 2

Lista de itens de verificação

\begin{tabular}{|c|c|c|}
\hline Item & Evidenciação & ITG 2003 \\
\hline 1 & Publicação das demonstrações obrigatórias & Item 16 \\
\hline 2 & Publicação da Demonstração do Valor Adicionado & - \\
\hline 3 & Natureza do ativo intangível & Item $15(a)$ \\
\hline 4 & Prazo de amortização & Item 7 \\
\hline 5 & Amortização acumulada & Item 7 \\
\hline 6 & Amortização do exercício & Item 17 (a) \\
\hline 7 & Valores gastos com a formação e aquisição de direitos contratuais & Item 4 (a) \\
\hline 8 & Separação por tipo e categoria & Item $15(a, b)$ \\
\hline 9 & Informação se realizou o teste no valor recuperável & Item 8 \\
\hline 10 & $\begin{array}{l}\text { Informação se o teste resultou na ocorrência ou não de uma perda no valor } \\
\text { recuperável }\end{array}$ & Item 8 \\
\hline 11 & Total de atletas vinculados ao clube & Item 17 (d) \\
\hline 12 & Direito econômico individual & Item 17 (d) \\
\hline 13 & Seguro de atletas & Item $17(e)$ \\
\hline
\end{tabular}

Nota. Adaptada da "Resolução 1.429," 2013.

Além das demonstrações obrigatórias, o estudo também buscou verificar se algum clube divulga voluntariamente a DVA (item 2), considerando que ela não é exigida pela ITG 2003 R1. A intenção é verificar se o clube informa a riqueza gerada e como foi distribuída.

Quanto à análise do ativo intangível de cada clube, primeiramente se verificou a natureza do ativo (item 3 ), em razão de não serem apenas os atletas que são classificados como intangível, por exemplo, software e marcas. Além disso, verificou-se se a aquisição de direitos contratuais, desde luvas até demais gastos para contratação ou renovação do contrato, e os valores gastos com a formação de atletas são classificados no intangível. Analisou-se também se o clube divulga a amortização de acordo com o prazo do contrato (itens 4, 5 e 6), bem como os gastos com formação e montante amortizado no exercício (item 7), e se faz isso por tipo-alojamento, alimentação, transporte, educação, vestuário, comissão técnica - e categoria-infantil, juvenil e juniores (item 8).

A ITG 2003 RT apoia que seja realizada no findar de cada exercício social uma avaliação dos direitos contratuais de cada atleta para verificar a possibilidade de recuperação, e caso se confirme que houve uma redução na capacidade de recuperação, total ou parcial, o clube poderá registrar uma perda correspondente ao valor não recuperável constatado no ativo. A análise do teste no valor recuperável foi dividida em duas etapas, nas quais foram analisados os itens 9 e 10. Quanto ao item 9, foi verificado se o clube evidenciou que realizou o teste no valor recuperável. Se o clube expôs apenas o conhecimento do teste não indicando se realizou ou não, foi atribuído zero. Se o clube afirmou a realização do teste, foi atribuído l, e nas situações em que ele informou que não encontrou indícios de perda e por isso não 
realizou o teste, foi atribuído 1. Enquanto no que tange ao item 10, foi verificado se o clube apresentou a informação se o teste resultou ou não em uma perda e/ou reversão no valor recuperável; caso o clube não encontrou indícios, foi atribuído "NA".

Os clubes devem ainda divulgar a composição dos direitos sobre os atletas, com gastos e amortizações, o número de atletas vinculados (item 11) e o percentual de direito econômico individual, ou a inexistência dele (item 12). Por fim, a Lei 9.615 (1998), em seu artigo 45, determina que o clube tenha um seguro de vida de seus atletas profissionais (item 13).

\subsubsection{Desempenho Econômico Financeiro e Modelo de Regressão com Dados em Painel}

Para avaliar o desempenho econômico-financeiro foram utilizadas seis medidas de análise, conforme literatura: receita líquida (Cordeiro, 2014, Holanda al., 2012, Leite \& Pinheiro, 2014); resultado líquido exercício (Holanda et al., 2012); patrimônio líquido, ativo intangível, ativo total (Benin et al., 2019, Silva et al., 2017, Umbelino et al., 2019); e intangibilidade (Leite $\&$ Pinheiro, 2014, Mota et al., 2016).

Com relação à receita líquida $(R L)$, no futebol é um indicador de grande importância em decorrência de os clubes serem alvos de grandes receitas, como: participação em competições nacionais e estaduais, transmissão televisiva, publicidade, bilheteria, mensalidade dos sócios e venda de artigos relacionado ao clube. Se o clube não apresentar a receita líquida, utiliza-se a receita bruta. $O$ resultado do exercício (RE) tem por finalidade averiguar se, apesar de as grandes receitas, o desempenho econômico-financeiro da empresa no geral foi satisfatório. É uma medida importante, pois mede se a empresa durante o ano obteve rentabilidade. Além disso, mesmo tendo altas receitas, muitos clubes possuem resultados negativos (Dahlbäck \& Lind, 2016; Romão \& Castellar, 2008).

O patrimônio líquido $(P L)$ representa o valor do clube ao longo dos anos, sendo o reflexo dos resultados anteriores e o capital inicial do clube, enquanto o ativo total (AT) demonstra o tamanho do clube; espera-se que quanto maior o tamanho, maior a evidenciação do clube. Já o intangível (AI) representa o quanto o clube investiu em jogadores, profissionais ou não, visto que parte do intangível a atividade do clube. A intangibilidade (INT) é a razão entre o ativo intangível e o ativo total, a qual expressa a representatividade do intangível.

Além das variáveis de desempenho econômico-financeiro, foi utilizada outra variável explicativa, a auditoria (AUD), que faz jus ao artigo 27, § 6, inciso V da Lei 9.615 (1998) alterada pelas Leis 10.672 (2003) e 12.395 (2011), em que as demonstrações financeiras devem ser apresentadas com o relatório de auditores independentes. Essa variável foi analisada por meio de uma dummy, na qual a empresa que publicou o relatório dos auditores recebeu 1 (um), caso contrário recebeu 0 (zero). 
Assim, foram coletados os dados relativos às variáveis dos clubes componentes da amostra de pesquisa nos anos de 2013, 2014, 2015 e 2016, a qual representa o período atual de vigor da ITG 2003 RI (Lei 1.429, 2013). A associação entre o nível de evidenciação (NE), o desempenho econômico-financeiro e a variável auditoria foi analisada por meio de uma regressão de dados em painel; a partir das variáveis selecionadas com base na literatura, foi elaborada a Equação 2, conforme demonstrada a seguir:

$N E_{i, t}=\alpha_{0}+\alpha_{1} R L_{i, t}+\alpha_{2} R E_{i, t}+\alpha_{3} P_{i, t}+\alpha_{4} A T_{i, t}+\alpha_{5} A_{i, t}+\alpha_{6} I N T_{i, t}+\alpha_{7} A U D_{i, t}+\varepsilon$

Espera-se uma associação positiva entre a variável dependente e as explicativas. A regressão será realizada por meio do software $S_{t a t a}{ }^{\circledR}$ com dados em painel curto, estimado pelo modelo de efeito fixo, conforme Tabela 3, que apresenta o resultado dos testes $\mathrm{F}$ de Chow, Langrang multiplier de Breush-Pagan e o de Hausman. Para controle de heterocedasticidade, os modelos foram estimados com coeficiente robusto, por meio do acréscimo do "cluster id" na regressão.

Tabela 3

Teste de estimadores do modelo

\begin{tabular}{|c|c|c|c|c|c|}
\hline Testes & P. Value & $\mathrm{H}_{\mathrm{o}}$ & $\mathrm{H}_{1}$ & Rejeita $\mathrm{H}_{0}$ & Modelo adequado \\
\hline Chow & 0,0000 & POLS & Efeito fixo & Sim & Efeito fixo \\
\hline LM Breusch-Pagan & 0,0000 & POLS & Efeito aleatório & Sim & Efeito aleatório \\
\hline Hausman & 0,0171 & Efeito Aleatório & Efeito fixo & Sim & Efeito fixo \\
\hline
\end{tabular}

\section{RESULTADOS DA PESQUISA}

O nível de evidenciação dos clubes de futebol ao longo dos quatro anos está descrito na Tabela 4, na qual se pode observar que em grande maioria o nível de evidenciação foi se adaptando à ITG $2003 \mathrm{Rl}$, porém os clubes ainda não atendem inteiramente a essa norma.

Clubes como Coritiba, Botafogo, Santos e São Paulo mantiveram o nível de evidenciação alto em 2015 e 2016, enquanto Bahia, Vitória, Grêmio e Ponte Preta reduziram seus níveis de evidenciação. Ressalta-se que o Clube Ponte Preta, em 2013, não estava de acordo com a ITG 2003 Rl, e em 2014 e 2015 atendeu a 38,46\% da métrica estabelecida, percentual que decaiu no ano seguinte.

Nota-se também que alguns clubes, como Náutico, Paysandu e Guarani apresentaram o nível de evidenciação apenas de um ano, pelo fato de ter ano em que as demonstrações não foram encontradas e outros que evidenciaram apenas o balanço patrimonial e a demonstração do resultado, o qual prejudicaria a análise. A Tabela 4 demonstra, ainda, que o maior nível de evidenciação foi do São Paulo, com 96,15\% nos anos de 2014 e 2015, o 
qual preencheu todos os itens da métrica, exceto o prazo de amortização, que evidenciou parcialmente, visto que apresentou a taxa de amortização do software, marcas e patentes, mas não apresentou dos seus jogadores profissionais.

Tabela 4

Nível de evidenciação dos clubes de futebol por ano

\begin{tabular}{|c|c|c|c|c|c|c|c|c|c|}
\hline Clube-Estado & 2013 & 2014 & 2015 & 2016 & Clube-Estado & 2013 & 2014 & 2015 & 2016 \\
\hline Bahia-BA & $38,46 \%$ & $46,15 \%$ & $57,69 \%$ & $42,31 \%$ & Fluminense-RJ & $46,15 \%$ & $61,54 \%$ & $69,23 \%$ & $69,23 \%$ \\
\hline Vitória-BA & - & - & $53,85 \%$ & $50,00 \%$ & Vasco-RJ & $30,77 \%$ & $38,46 \%$ & $30,77 \%$ & $38,46 \%$ \\
\hline Ceará-CE & - & - & $7,69 \%$ & $15,38 \%$ & Grêmio-RS & $57,69 \%$ & $69,23 \%$ & $76,92 \%$ & $69,23 \%$ \\
\hline Goiás-GO & $50,00 \%$ & $69,23 \%$ & $76,92 \%$ & $83,33 \%$ & Internacional-RS & $69,23 \%$ & $61,54 \%$ & $69,23 \%$ & $69,23 \%$ \\
\hline América-MG & - & $23,08 \%$ & & $38,46 \%$ & Avaí-SC & $73,08 \%$ & $73,08 \%$ & $69,23 \%$ & $69,23 \%$ \\
\hline Atlético-MG & $38,46 \%$ & $38,46 \%$ & $61,54 \%$ & $75,00 \%$ & Chapecoense-SC & - & - & $46,15 \%$ & $53,85 \%$ \\
\hline Cruzeiro-MG & $57,69 \%$ & $57,69 \%$ & $57,69 \%$ & $65,38 \%$ & Criciúma-SC & $61,54 \%$ & $53,85 \%$ & $61,54 \%$ & $61,54 \%$ \\
\hline Paysandu-PA & - & - & - & $19,23 \%$ & Figueirense-SC & $57,69 \%$ & $57,69 \%$ & $57,69 \%$ & $65,38 \%$ \\
\hline Náutico-PE & $30,77 \%$ & - & & - & Corinthians-SP & $61,54 \%$ & $53,85 \%$ & & $76,92 \%$ \\
\hline Santa Cruz-PE & - & $38,46 \%$ & - & - & Guarani-SP & - & - & $53,85 \%$ & 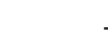 \\
\hline Sport-PE & $38,46 \%$ & $50,00 \%$ & - & $50,00 \%$ & Palmeiras-SP & $61,54 \%$ & $61,54 \%$ & $75,00 \%$ & $75,00 \%$ \\
\hline Atlético-PR & $38,46 \%$ & $38,46 \%$ & $46,15 \%$ & $46,15 \%$ & Ponte Preta-SP & - & $38,46 \%$ & $38,46 \%$ & $30,77 \%$ \\
\hline Coritiba-PR & $84,62 \%$ & $76,92 \%$ & $92,31 \%$ & $92,31 \%$ & Santos-SP & $84,62 \%$ & $92,31 \%$ & $92,31 \%$ & $92,31 \%$ \\
\hline Botafogo-RJ & $53,85 \%$ & $76,92 \%$ & $92,31 \%$ & $92,31 \%$ & São Paulo-SP & $73,08 \%$ & $96,15 \%$ & $96,15 \%$ & $95,83 \%$ \\
\hline Flamengo-RJ & $61,54 \%$ & $61,54 \%$ & $61,54 \%$ & $61,54 \%$ & & & & & \\
\hline
\end{tabular}

Em 2016, o São Paulo também teve o maior nível de evidenciação, com 95,83\%, e apresentou o mesmo que em 2014 e 2015, mantendo o padrão, exceto pelo item 10 sobre - resultado do teste de recuperabilidade, que recebeu um "não aplicável". Em 2013, o maior nível de evidenciação foi do Santos, com $84,62 \%$, que não divulgou os gastos com a formação dos jogadores e o prazo de amortização. Em contrapartida, o Ceará apresentou o menor índice, com 7,69\%. Em 2015 pontuou apenas no item um referente à publicação das demonstrações contábeis, já em 2016 pontuou em dois quesitos; além das demonstrações também evidenciou o valor da amortização do exercício, no item seis.

Os dados descritivos dos clubes podem ser observados na Tabela 5, na qual se notam o mínimo e o máximo descritos anteriormente, além de que, no geral, o nível de evidenciação foi de 59,64\%, próximo à mediana, o que torna os resultados semelhantes, visto que praticamente metade dos dados está acima da média. A média de evidenciação foi superior a Marques et al. (2017) e Souza et al. (2016), o que indica que os clubes de futebol estão melhorando suas divulgações e adaptando-se à norma, como era esperado por Marques et al. 
Tabela 5

Estatística descritiva do nível de evidenciação por ano

\begin{tabular}{|c|c|c|c|c|c|}
\hline Estatística/Ano & 2013 & 2014 & 2015 & 2016 & Geral \\
\hline Número de observações & 21 & 23 & 23 & 26 & 93 \\
\hline Média & $55,68 \%$ & $58,03 \%$ & $62,79 \%$ & $61,48 \%$ & $59,64 \%$ \\
\hline Mediana & $57,69 \%$ & $57,69 \%$ & $61,54 \%$ & $65,38 \%$ & $61,54 \%$ \\
\hline Desvio padrão & 0,1607 & 0,1815 & 0,2116 & 0,2211 & 0,1956 \\
\hline Mínimo & $30,77 \%$ & $23,08 \%$ & $7,69 \%$ & $15,38 \%$ & $7,69 \%$ \\
\hline Máximo & $84,62 \%$ & $96,15 \%$ & $96,15 \%$ & $95,83 \%$ & $96,15 \%$ \\
\hline
\end{tabular}

A Tabela 6 mostra por ano o número de adesão de cada item da métrica, na qual o item que foi cumprido em todos os anos foi a publicação das demonstrações obrigatórias (item um), resultado que corrobora o estudo de Souza et al. (2016). Em contrapartida, a publicação da DVA teve 16 publicações no período analisado, sendo ainda baixa a adesão dos clubes, consequentemente ocultando informações que poderiam ser úteis à sociedade.

Tabela 6

Nível de evidenciação por item

\begin{tabular}{|c|c|c|c|c|c|}
\hline Item & Descrição & 2013 & 2014 & 2015 & 2016 \\
\hline 1 & Publicação das demonstrações obrigatórias & 21,0 & 23,0 & 23,0 & 25,5 \\
\hline 2 & Publicação da Demonstração do Valor Adicionado & 3,0 & 2,0 & 4,0 & 7,0 \\
\hline 3 & Natura do intangível & 21,0 & 22,0 & 22,0 & 25,0 \\
\hline 4 & Prazo de amortização & 6,5 & 4,5 & 3,0 & 4,5 \\
\hline 5 & Amortização acumulada & 15,0 & 18,0 & 14,0 & 15,0 \\
\hline 6 & Amortização do exercício & 15,0 & 16,0 & 16,0 & 19,0 \\
\hline 7 & Valores gastos com a formação e aquisição de direitos contratuais & 11,0 & 14,0 & 13,0 & 18,0 \\
\hline 8 & Separação por tipo e categoria & 20,0 & 20,0 & 22,0 & 25,0 \\
\hline 9 & Informação se realizou o teste no valor recuperável & 4,0 & 8,0 & 10,0 & 10,0 \\
\hline 10 & Informação o resultado do teste de perda no valor recuperável & 4,0 & 8,0 & 9,0 & 5,0 \\
\hline 11 & Total de atletas vinculados ao clube & 12,5 & 14,0 & 19,0 & 19,0 \\
\hline 12 & Direito econômico individual & 7,0 & 10,0 & 14,0 & 14,0 \\
\hline 13 & Seguro de atletas & 12,0 & 14,0 & 18,0 & 17,0 \\
\hline- & Número de observações & 21,0 & 23,0 & 23,0 & 26,0 \\
\hline
\end{tabular}

O item 5-amortização acumulada, que pode ser evidenciada no balanço patrimonial ou na nota explicativa do intangível, foi evidenciada em 62 demonstrações (67\%), sendo inferior ao estudo de Souza et al. (2016), que obtiveram um nível de aderência de $84 \%$.

Os itens 9 e 10 sobre o teste de recuperabilidade estavam presentes nas práticas contábeis, porém, sem qualquer indício de realização. Observa-se uma falta de informação com relação ao teste de recuperabilidade, visto que em todos os anos menos da metade dos clubes evidenciaram sua realização e/ou resultado, problema persistente, visto que aproximadamente $65 \%$ dos clubes estudados por Maia e Vasconcelos (2016) também não 
evidenciaram o teste, sendo um dos itens menos evidenciados, conforme encontrado por Leite e Pinheiro (2014).

Quanto ao item 12, alguns clubes relataram que deixaram de apresentar o percentual em razão de sigilo comercial, outros não apresentaram justificativa para não apresentação. Da amostra, 45 (48,39\%) apresentaram o percentual econômico, enquanto 64,5 (69,35\%) evidenciaram o total de atletas (item 11); os resultados se mostram superiores ao de Souza et al. (2016), em que apenas $21 \%$ evidenciaram os direitos econômicos, e ao de Maia e Vasconcelos (2016), em que o número de atletas foi evidenciado por apenas 6 clubes de futebol (9,09\%).

Já quanto ao item 13-seguro de atletas, obrigatório pelo artigo 45 da Lei 9.615 (1998), alguns clubes não evidenciaram, enquanto outros falaram que possuíam seguro, mas não especificaram que era dos atletas, ou então apenas informaram que o seguro era referente aos interesses do clube, o que foi atribuído zero, prejudicando a métrica da equipe no ano. Entre os clubes pesquisados, 61 (65,59\%) cumpriram o quesito, quase 8 pontos percentuais a mais que o estudo de Souza et al. (2016).

Ressalta-se que apesar de não fazerem parte da métrica, alguns clubes, como Santos e São Paulo, evidenciaram um detalhamento das transações realizadas no período com a venda de atletas, detalhando o valor da receita, e o destino do jogador, bem como se o valor foi inteiro ou parcialmente pago. Além disso, o Atlético-PR foi o único que evidenciou com as demonstrações contábeis o seu Balanço Social nos quatro anos aqui estudados. O Ponte Preta, em 2014 e 2015, reavaliou seus jogadores, aumentando o valor do ativo mesmo que não tenham ocorrido perdas anteriormente, o que vai de encontro à legislação brasileira sobre reavaliação de ativos. Já o Internacional apresentou os gastos mensais com os jogadores em formação, esses gastos deveriam ser divulgados mensalmente, porém o Clube cumpriu uma das exigências da ITG $2003 \mathrm{Rl}$, apesar desse item também não pertencer à métrica.

A Tabela 7 apresenta a estatística descritiva das variáveis utilizadas; o maior ativo intangível pertence ao São Paulo em todos os anos, sendo que em 2013 também apresentou a maior receita líquida. Enquanto a menor receita líquida e o ativo intangível pertencem, em 2013, ao Avaí e ao Náutico, respectivamente.

Tabela 7

Estatística descritiva das variáveis (em milhares de reais)

\begin{tabular}{llrrrrr}
\hline Ano & \multicolumn{1}{c}{ Conta } & \multicolumn{1}{c}{ Média } & \multicolumn{1}{c}{ Mediana } & Desvio padrão & \multicolumn{1}{c}{ Máximo } & \multicolumn{1}{c}{ Mínimo } \\
\hline \multirow{2}{*}{2013} & Receita Líquida do clube & 141.761 & 150.229 & 95.821 & 362.832 & 19.192 \\
& Resultado Líquido & -15.524 & -6.664 & 32.934 & 40.621 & -113.062 \\
& Patrimônio Líquido & -17.807 & 13.000 & 242.084 & 421.357 & -614.996 \\
& Ativo Intangível & 44.825 & 39.696 & 47.829 & 196.337 & 1.110 \\
& Ativo Total & 349.750 & 288.902 & 320.009 & 1.280 .977 & 24.094 \\
& \% Intangibilidade & $16,53 \%$ & $16,61 \%$ & $15,46 \%$ & $62,75 \%$ & $0,61 \%$ \\
\hline
\end{tabular}




\begin{tabular}{llrrrrr}
\hline Ano Conta & \multicolumn{1}{c}{ Média } & \multicolumn{1}{c}{ Mediana } & Desvio padrão & \multicolumn{1}{c}{ Máximo } & \multicolumn{1}{c}{ Mínimo } \\
\hline \multirow{2}{*}{2014} & Receita Líquida do clube & 128.820 & 113.492 & 90.098 & 334.308 & 14.946 \\
& Resultado Líquido & -11.992 & -8.940 & 70.932 & 230.561 & -174.844 \\
& Patrimônio Líquido & -22.551 & 2.121 & 252.625 & 372.275 & -790.100 \\
& Ativo Intangível & 44.944 & 33.989 & 49.371 & 200.774 & 78 \\
& Ativo Total & 358.616 & 250.265 & 347.943 & 1.453 .117 & 25.100 \\
& \% Intangibilidade & $17,51 \%$ & $10,62 \%$ & $20,08 \%$ & $80,87 \%$ & $0,03 \%$ \\
\hline \multirow{2}{*}{2015} & Receita Líquida do clube & 141.482 & 91.985 & 114.793 & 351.480 & 5.086 \\
& Resultado Líquido & 12.001 & 1.050 & 52.215 & 130.450 & -78.190 \\
& Patrimônio Líquido & -31.116 & -10.408 & 222.532 & 399.237 & -681.300 \\
& Ativo Intangível & 46.977 & 29.904 & 44.974 & 160.857 & 9 \\
& Ativo Total & 324.838 & 249.311 & 313.120 & 1.047 .094 & 4.372 \\
& \% Intangibilidade & $16,52 \%$ & $15,36 \%$ & $12,11 \%$ & $52,90 \%$ & $0,21 \%$ \\
\hline Receita Líquida do clube & 183.586 & 123.399 & 145.566 & 483.493 & 20.357 \\
& Resultado Líquido & 19.614 & 5.783 & 38.851 & 153.478 & -29.318 \\
Patrimônio Líquido & 3.851 & -2.259 & 213.958 & 388.079 & -690.543 \\
Ativo Intangível & 59.242 & 36.173 & 58.952 & 198.865 & 639 \\
Ativo Total & 403.681 & 216.215 & 481.338 & 2.164 .040 & 7.081 \\
\% Intangibilidade & $17,01 \%$ & $16,34 \%$ & $11,03 \%$ & $45,49 \%$ & $1,88 \%$ \\
\hline
\end{tabular}

O menor percentual de intangibilidade pertence ao Náutico, em contrapartida, o maior (62,75\%) pertence ao Santos. Percebe-se que o Resultado Líquido (RE) e o Patrimônio Líquido (PL) possuem médias negativas tanto em 2013 quanto em 2014, sendo que o menor RE de 2013 pertence ao Bahia, enquanto o de 2014 e o PL de ambos os anos pertencem ao Botafogo. O Botafogo, aliás, apresentou o menor patrimônio líquido em todos os anos.

Em 2014, o Corinthians apresentou o maior resultado líquido e o maior ativo total; em contrapartida, o Ponte Preta apresentou o menor ativo intangível e ficou responsável pela menor intangibilidade, enquanto a maior foi representada pelo Santa Cruz com cerca de $80 \%$, Clube com a menor receita do ano. Em 2015, o São Paulo apresentou o maior ativo total, assim como o maior intangível, porém, a maior intangibilidade foi do Santos, assim como em 2013 e em 2016. Este, por sinal, apresentou o menor resultado líquido do ano, enquanto o Flamengo apresentou o maior, assim como em 2016 com a receita. A maior e a menor receita líquida de 2015 pertencem ao Palmeiras e ao Guarani, respectivamente. Em 2016, o Cruzeiro e o Avaí obtiveram o menor resultado e receita líquida, respectivamente. Com relação ao patrimônio líquido, o Internacional apresentou o maior em todos os anos.

Em suma, pode-se perceber que apesar de os valores médios da receita líquida anual serem altos, o resultado líquido foi negativo em 2013 e 2014, e obteve-se uma média baixa em 2015 e 2016, de modo que se pode inferir que os clubes possuem uma receita grandiosa, porém seus gastos são superiores, o que impossibilita que o resultado seja positivo. Esse achado corrobora o estudo de Romão e Castellar (2008), que encontraram apenas 6 de 21 clubes com resultados positivos, apesar de a receita ser superior a 11 milhões de reais em 2007. 
Com a finalidade de verificar se as variáveis possuem correlação entre si, foi realizado o teste de correlação de Pearson, no qual se observou que a variável Receita Líquida (RL) apresentou uma alta correlação com as variáveis Ativo Total (AT) e Ativo Intangível (AI). Por serem comumente utilizadas como medidas de tamanho, RL e AT, essa correlação era esperada. Com relação ao Ativo Intangível, estará correlacionado à Receita Líquida, o que demonstra que os clubes com maiores intangíveis-ou seja, contratos com atletas com valores mais expressivostendem a possuir um desempenho maior com a arrecadação de receitas, como patrocinadores, bilheteria e venda de artigos esportivos. Dessa forma, primeiramente, optou-se por apresentar nos resultados as regressões com todas as variáveis, e posteriormente excluir as variáveis $\mathrm{RL}$ e $\mathrm{AT}$, deixando apenas a variável Al em decorrência de ser o objeto de estudo.

As variáveis da Tabela 7 correspondem às variáveis explicativas representativas da situação econômica e financeira para análise da associação com o nível de evidenciação do intangível nos clubes. Adicionou-se a variável dummy referente à Auditoria, conforme já exposto na metodologia. A regressão com todas as variáveis pode ser observada na Tabela 8:

Tabela 8

Regressão entre o nível de evidenciação e as variáveis explicativas

\begin{tabular}{lrrrr}
\hline \multicolumn{1}{c}{ Variável } & Painel A & & \\
\hline Constante & Coeficiente & Erro padrão & Teste T & p-value \\
Receita Líquida (RL) & 0,6062468 & 0,0735923 & 8,24 & 0,000 \\
Resultado Líquido do Exercício (RE) & 0,00000012 & 0,0000032 & 0,39 & 0,696 \\
Patrimônio Líquido (PL) & 0,00000043 & 0,0000002 & 1,98 & 0,058 \\
Ativo Intangível (AI) & $-0,00000045$ & 0,0000002 & $-2,24$ & 0,020 \\
Ativo Total (AT) & 0,0000027 & 0,0000010 & 2,83 & 0,008 \\
Intangibilidade (INT) & $-0,00000005$ & 0,0000001 & $-0,59$ & 0,560 \\
Auditoria (AUD) & $-0,0075805$ & 0,0029201 & $-2,60$ & 0,015 \\
\hline Painel B & $-0,02666001$ & 0,0492089 & $-0,54$ & 0,593 \\
\hline$R^{2}$ within & & & \\
$R^{2}$ between & 0,3563 & Número de observações & & \\
R $^{2}$ overall & 0,1222 & Teste F & 0,33 \\
\hline
\end{tabular}

modelo foi estatisticamente significativo, em razão de o p-value do teste $F$ ser inferior a 5\%. Quanto ao poder explicativo foi baixo, o que indica que $11,84 \%$ do nível de evidenciação estão associado ao desempenho econômico-financeiro. As variáveis $R L, A T$ e AUD não foram significativas estatisticamente, de forma que não podem ser associadas ao nível de evidenciação no intangível. Com relação à variável dummy de Auditoria, praticamente todos os clubes apresentaram, sendo posto "um" em 86 de 93 clubes, o que demonstra que a maior parte dos clubes tende a apresentar o parecer de auditoria. Os clubes que não publicaram com suas demonstrações contábeis o relatório dos auditores independentes foram Náutico e Vasco da Gama, em 2013; Flamengo, Santa Cruz e Santos, 
em 2014; e América, MG e Paysandu, em 2016. Ressalta-se que em 2015 todos os clubes analisados apresentaram o parecer dos auditores.

Já a variável Receita Líquida contradiz os resultados de Benin et al. (2019), Cordeiro (2014) e Holanda et al. (2019), visto que os estudos apontaram que quanto maior a receita, mais transparentes são os clubes, e o fato de a variável não ter sido significativa neste estudo compromete o entendimento dos fatores que possam explicar a evidenciação.

Com relação ao modelo, observado pelo p-value do teste $T$, as variáveis $R E$ e PL foram estatisticamente significativas a $10 \%$ e $5 \%$, respectivamente. Já as variáveis Al e INT tiveram significância estatística de $1 \%$. Contudo, apesar de serem válidas no modelo, as variáveis que possuem associação positiva com o nível de evidenciação são apenas $\operatorname{RE} e$ Al, visto que os sinais dos seus coeficientes são ambos positivos, ao contrário do Patrimônio Líquido e Intangibilidade que tiveram o sinal oposto. A Intangibilidade foi significativa, diferente dos achados de Leite e Pinheiro (2014), porém negativamente associada ao nível de evidenciação, divergindo do resultado de Mota et al. (2016), no qual a Intangibilidade (materialidade do intangível) é positivamente relacionada ao nível de disclosure.

Conclui-se, portanto, que quanto maior o Resultado Líquido do clube, mais informações sobre intangíveis ele divulga, visto que pelos coeficientes a cada um mil reais em resultado, o nível de evidenciação tende a aumentar 0,60. Esses achados podem ter relação com o fato de quanto mais recursos intangíveis existentes nas entidades, maior transparência é necessária por parte delas. Isso pode ser explicado também pelos valores altos envolvidos nos contratos exigirem que os clubes respeitem a evidenciação mínima exigida por lei.

Por conseguinte, optou-se por retirar da regressão o AT, bem como a RL em decorrência da alta correlação entre elas conforme exposto, além de que ambas variáveis não são significativas no modelo. Ademais, a variável auditoria foi excluída da regressão, em razão da não significância anteriormente relatada. $O$ output da regressão encontra-se na Tabela 9:

Tabela 9

Regressão entre o nível de evidenciação e as variáveis explicativas

\begin{tabular}{lrrrr}
\hline & \multicolumn{1}{c}{ Painel A } & & \\
\hline Variável & Coeficiente & Erro padrão & Teste T & p-value \\
\hline Constante & 0,5746846 & 0,0219296 & 26,21 & 0,000 \\
Resultado Líquido do Exercício (RE) & 0,0000005 & 0,0000002 & 1,93 & 0,064 \\
Patrimônio Líquido (PL) & $-0,0000005$ & 0,0000002 & $-2,48$ & 0,019 \\
Ativo Intangível (AI) & 0,0000027 & 0,0000004 & 6,80 & 0,000 \\
Intangibilidade (INT) & $-0,0072057$ & 0,0016668 & $-4,32$ & 0,000 \\
\hline & Painel B & & 93 \\
\hline$R^{2}$ within & 0,3494 & Número de observações & 12,90 \\
$R^{2}$ between & 0,1441 & Teste F & 0,0000 \\
$R^{2}$ overall & 0,1254 & p-value F & \\
\hline
\end{tabular}

Nota. Equação 3-modelo de regressão: $\mathrm{NE}_{\mathrm{i}, \mathrm{t}}=\alpha_{\mathrm{o}}+\alpha_{1} \mathrm{RE}_{\mathrm{i}, \mathrm{t}}+\alpha_{2} \mathrm{PL}_{\mathrm{i}, \mathrm{t}}+\alpha_{3} \mathrm{Al}_{\mathrm{i}, \mathrm{t}}+\alpha_{4} \mathrm{INT}_{\mathrm{i}, \mathrm{t}}+\varepsilon$. 
Pode-se observar que a exclusão das variáveis da Equação 3 melhorou o poder explicativo, visto que passou de $11,84 \%$ para $12,54 \%$, obtendo um aumento de 0,7 ponto percentual, o que resulta em um acréscimo de 5,91\%. Quanto ao modelo, é significante de acordo com o Teste $\mathrm{F}$ ao nível de $1 \%$. Entre as variáveis explicativas, todas foram significantes ao nível de confiança de $1 \%$, exceto o $\mathrm{RE}$, que foi significante ao nível de $10 \%$. Porém, assim como no modelo proposto pela Equação 2, as variáveis PL e INT estão negativamente associadas ao nível de evidenciação dos ativos intangíveis dos clubes de futebol brasileiros, enquanto as variáveis RE e Al estão positivamente associadas.

Uma possível explicação para os resultados relativos ao PL é que os clubes, por apresentarem Passivo a Descoberto (média negativa de 2013 a 2015), deixem de evidenciar para que suas demonstrações não transmitam que um possível amadorismo do gestor acarretou problemas financeiros, como apontado por Russano e Marinho, (2007). Já a INT mostra que clubes com intangíveis altos tendem a evidenciar menos, isso podendo ser explicado por motivos internos de sigilo, como apontado em uma nota explicativa.

Finalmente, os achados demonstram que o nível de evidenciação pode estar associado ao $\mathrm{Al}$, visto que os clubes de futebol registram seus atletas no intangível e os valores dos contratos englobam inclusive luvas e cláusulas compensatórias e de comissões.

Além disso, o RE pode estar associado ao nível de evidenciação em razão dos valores recebidos de direitos de imagem, bem como da venda dos atletas, visto que o período de transações entre clubes ocorre em período diferente ao da publicação das demonstrações. Destarte, a evidenciação auxilia os torcedores e demais interessados no desempenho econômico-financeiro do clube sobre os impactos (positivos ou negativos) da venda ou compra dos atletas. Desse modo, uma evidenciação adequada e com mais detalhes, divulgando além do que é exigido por lei, como dos clubes Santos e São Paulo, torna as demonstrações contábeis mais úteis, cumprindo, assim, seu papel principal.

\section{CONSIDERAÇÕES FINAIS}

Com o intuito de verificar se os clubes de futebol estão classificando seus atletas adequadamente, e se estão de acordo com a legislação, o objetivo desta pesquisa foi verificar a associação entre o nível de evidenciação dos ativos intangíveis e o desempenho econômico-financeiro dos clubes de futebol brasileiros.

Alguns clubes não divulgarem seus balanços, ou se divulgaram, apresentaram parcialmente o conjunto das demonstrações obrigatórias. Entre os clubes analisados, percebeu-se que estão classificando adequadamente seus atletas, visto que de 2013 para 2016 caiu de quatro para um em desacordo com a ITG 2003 R1. Além disso, a média de 
evidenciação foi de $59,64 \%$ e a mediana de $61 \%$, o que leva à apresentação de um índice de evidenciação igual ou superior a $50 \%$ de mais da metade dos clubes ao longo dos quatro anos. Esses resultados são similares aos de Dahlbäck e Lind (2016), ou seja, a evidenciação do ativo intangível está presente nas demonstrações contábeis, porém nem sempre evidencia o que a legislação dispõe como o mínimo necessário. Essa falta de informação pode ocorrer pelo fato de o gestor não considerar material a divulgação da referida informação, ou o gestor, por algum motivo interno ou externo, não querer disponibilizar essa informação. Por exemplo, um jogador teve seus direitos vendidos a terceiros, mas continua no clube formador, o clube opta por não divulgar os direitos econômicos dos jogadores, mesmo sendo obrigatório, com o intuito de evitar confronto dos usuários externos.

Mesmo sendo de opção da entidade desportiva divulgar ou não certas informações, alguns itens, como o teste de recuperabilidade e o prazo contratual dos atletas são itens que devem ser mais evidenciados, visto que são importantes para garantir que esses intangíveis estão mensurados ao menos pelo seu valor recuperável e o prazo que esses benefícios estão sendo esperados em razão do tempo contratual. Da mesma maneira, alguns clubes divulgaram itens que não pertenciam à métrica, como o Balanço Social e os gastos mensais com a formação de atletas não profissionais, o que leva à conclusão que alguns clubes poderiam evidenciar mais seus intangíveis de acordo com a norma. Ressalta-se que os sócios dos clubes de futebol podem exigir que os gestores sejam mais transparentes com a evidenciação das práticas adotadas, bem como valores e prazos contratuais dos seus atletas.

Uma evidenciação adequada das entidades desportivas pode acarretar maior número de investidores, como, por exemplo, patrocinadores que financiam clubes que apresentem bom desempenho, tanto nos campeonatos que participam quanto nas finanças. Os patrocinadores podem exigir dos clubes uma melhor evidenciação, até porque as entidades desportivas são patrocinadas muitas vezes por grandes instituições, financeiras ou não. Os torcedores também podem querer uma evidenciação mais ampla, tanto para ver como está a formação de novos jogadores quanto para ver a saúde financeira do clube, e a falta de adesão à norma compromete a comparabilidade das demonstrações (Figueiredo et al., 2017).

Cabe ressaltar que uma evidenciação ampla das demonstrações contábeis auxilia para a comparabilidade e aumenta a confiabilidade, informando como estão as obrigações do clube e induzindo que as transações das entidades desportivas foram legais e não houve desvios de dinheiro pela venda/compra dos jogadores. Como, por exemplo, as acusações (ainda não julgadas) na transferência do jogador Neymar do Santos para o Barcelona, em 2013.

Ao fazer uma comparação entre o nível de evidenciação e o desempenho econômicofinanceiro, percebeu-se uma associação positiva apenas entre as variáveis Ativo Intangível e Resultado Líquido do Exercício, de forma que quanto maior o intangível do clube, maior tende a ser sua evidenciação, da mesma forma para o resultado líquido; já a associação com o resultado líquido possivelmente pode ser explicada em razão dos clubes com maiores 
resultados, por serem mais visados pelos demais e tenderem a demonstrar maior transparência com relação aos seus intangíveis. No que compete à relação entre nível de evidenciação e ativo intangível, essa associação é mais evidente, visto que o Clube que obteve o maior nível de evidenciação em 2014, 2015 e 2016 também possui o maior ativo intangível entre os clubes estudados, que no caso foi o São Paulo.

A situação econômico-financeira dos clubes de futebol é importante para o País, e não apenas para os torcedores e imprensa (Umbelino et al., 2019). As receitas envolvidas provêm tanto de empresas privadas quanto de públicas, com ingressos, venda de jogadores, direitos de transmissão dos jogos, publicidade. Em contrapartida, tem-se as obrigações que são alvos constantes da crise financeira dos clubes em decorrência dos altos salários, além dos encargos envolvidos. Dessa maneira, conclui-se que a evidenciação adequada favorece todos os interessados nos clubes, devendo no mínimo obedecer ao requisitado pela legislação, sendo importante para a fiscalização dos órgãos reguladores sobre a maneira como o presidente conduz as finanças do clube, bem como a fiscalização dos torcedores e investidores sobre a forma de capitalizar a formação dos jogadores e negociação dos profissionais.

É importante ressaltar como limitação que os resultados e conclusões deste estudo estão limitados aos clubes e períodos analisados neste trabalho, não podendo ser transpostos para outros clubes nacionais ou internacionais ou períodos anteriores ou posteriores. Além disso, a métrica está limitada, que por sua vez contemplou 14 itens da ITG 2003 Rl, com foco no intangível. Para trabalhos futuros, sugere-se ampliar a amostra de pesquisa com a inclusão de todos os clubes de futebol brasileiros na análise, visando verificar se eles estão adaptados à nova legislação, bem como outros esportes. Além disso, realizar comparações entre clubes brasileiros e de outras nacionalidades.

\section{REFERÊNCIAS}

Alves, C., Behr, A., \& Raimundini, S. (2012). Mensuração e Evidenciação de Ativos Intangíveis em Demonstrações Contábeis: $O$ Estudo de Caso em um Clube de Futebol Brasileiro. Revista Catarinense da Ciência Contábil, 11(32), 9-25.

Bastos, P. S. S., Pereira, R. M., \& Tostes, F. P. (2007). Uma contribuição para a evidenciação do ativo intangível-atletas-dos clubes de futebol. Pensar contábil, 9(36).

Benin, M. M., Diehl, C. A., \& Figueira-Marquezan, L. H. (2019). Determinantes da evidenciação de indicadores não financeiros de desempenho por clubes brasileiros de futebol. Estudios Gerenciales, 35(150), 16-26.

Chik, M. (2017). Legal and regulatory aspects of the recognition and accounting of intangible assets. Oblik I Finansi, (3), 59-65. 
Confederação Brasileira de Futebol. (2017a). Regulamento Específico da Competição: Campeonato Brasileiro da Série A 2017.

Confederação Brasileira de Futebol. (2017b). Regulamento Específico da Competição: Campeonato Brasileiro da Série B 2017.

Cordeiro, J. V. L. (2014). Relação do nível de disclosure e as receitas arrecadadas pelos clubes brasileiros de futebol das séries "A" e "B" (Monografia de pós-graduação). Universidade Federal Rural do Semiárido, Mossoró.

Costa, C. E. S., \& da Silva, R. C. (2006). Empresarização e controle organizacional: Um estudo nos clubes de futebol em Santa Catarina. Cadernos EBAPE. BR, 4(4), 1-16.

Cruz, S. N. D. S. R., Santos, L. L., \& Azevedo, G. M. D. C. (2010). Valorização do direito desportivo resultante da formação. Revista de educação e pesquisa em contabilidade, $4(1), 60-83$.

Dahlbäck, O., Lind, E. (2016). Transparency in European football: A study of financial disclosure transparency from a supporter perspective (Master's dissertation). Jönköping International Business School, Jönköping, Suécia.

Decreto-Lei 3.199, 1941.

Dimitropoulos, P. E., \& Koumanakos, E. (2015). Intellectual capital and profitability in European football clubs. International Journal of Accounting, Auditing and Performance Evaluation, 11(2), 202-220. doi:10.1504/ijaape.2015.068862

Farias, C. D. C. M., \& Teixeira, B. de M. (2019). Evidenciação de direitos de imagem no ativo intangível em entidades desportivas profissionais. Revista Eletrônica de Ciências Sociais Aplicadas, 6(2), 24-48.

Figueiredo, G. H., Santos, V., \& Cunha, P. R. (2017). Práticas de evidenciação em entidades desportivas: Um estudo nos clubes de futebol brasileiros. Enfoque: Reflexão Contábil, $36(1), 1-21$.

Frey, I. A., \& Zaia, R. (2014). Demonstrações contábeis dos clubes de futebol do campeonato catarinense de 2012: Verificação da adequação à legislação vigente. REAVI-Revista Eletrônica do Alto Vale do Itajaí, 3(4), 12-24.

Gambeta, W. R. (2013). A bola rolou: O velódromo paulista e os espetáculos de futebol (1895/1916) (Tese de doutorado). Universidade de São Paulo, São Paulo. 
Hendriksen, E. S., \& Van Breda, M. F. (1999). Teoria da contabilidade (A. Zoratto Sanvicente, Trad.). São Paulo: Atlas.

Holanda, A. P., Meneses, A. F. D., Mapurunga, P. V. R., De Luca, M. M. M., \& Coelho, A. C. D. (2012). Determinantes do nível de disclosure em clubes brasileiros de futebol. Revista de Contabilidade do Mestrado em Ciências Contábeis da UERJ, 17(1), 2-17.

ludícibus, S. (2009). Teoria da contabilidade. São Paulo: Atlas.

Lei 8.672, 1993.

Lei $9.615,1998$.

Lei 10.672, 2003.

Lei 11.638, 2007.

Lei 11.941, 2009.

Lei 12.395, 2011.

Lei 13.155, 2015.

Leite, D. U., \& Pinheiro, L. E. T. (2014). Disclosure de Ativo Intangível: Um Estudo dos Clubes de Futebol Brasileiros. Enfoque Reflexão Contábil, 33(1), 89-104.

Machado, N. P., \& Nunes, M. S. (2006). A evidenciação das informações contábeis: Sua importância para o usuário externo. Business Review, 1(1), 111-121.

Maia, A. B. G. R., \& Vasconcelos, A. C. (2016). Disclosure de Ativos Intangíveis dos Clubes de Futebol Brasileiros e Europeus. Contabilidade Vista \& Revista, 27(3), 1-31.

Marques, V. A., Santos, G. R., Ferreira, C. O., Amaral, H. F., \& Souza, A. A. (2017). Nível de evidenciação das demonstrações contábeis dos clubes brasileiros de futebol. Revista Mineira de Contabilidade, 18(2), 28-40.

Mello, J., Gonçalves, F., Correia, F., \& Mourão, H. (2018). Percepções sobre valoração dos ativos intangíveis em clubes de futebol do Rio de Janeiro. Revista de Administração de Roraima-RARR, 7(2), 331-347. doi:10.18227/2237-8057rarr.v7i2.3989 
Mota, A. F., Brandão, I. F., \& Ponte, V. M. R. (2016). Disclosure e materialidade: evidências nos ativos intangíveis dos clubes brasileiros de futebol. RACE: Revista de Administração, Contabilidade e Economia, 15(1), 175-200. doi:10.18593/race.v15il.6326

Oliveira, D. S., Bianchi, M., \& Souza, R. B. D. L. (2014). Análise da implantação da padronização contábil nos times gaúchos de maior poder econômico: Grêmio Football Porto Alegrense e Sport. SINERGIA-Revista do Instituto de Ciências Econômicas, Administrativas e Contábeis, 18(1), 41-52.

Pronunciamento Técnico CPC $04 \mathrm{Rl}$, 2010. Recuperado de http://www.cpc.org.br/Arquivos/ Documentos/187_CPC_04_R1_rev\%2013.pdf

Resolução CFC 1.005, 2004.

Resolução CFC 1.429, 2013.

Rezende, A. J., \& Custódio, R. D. S. (2012). Uma análise da evidenciação dos direitos federativos nas demonstrações contábeis dos clubes de futebol brasileiros. Revista de Educação e Pesquisa em Contabilidade, 6(3), 229-245.

Rezende, A. J., Salgado, A. L., Ribeiro, E. M. S., \& Dalmacio, F. Z. (2008). Uma análise do tratamento contábil dos ativos intangíveis (jogadores de futebol) nos clubes brasileiros. Anais do Congresso Brasileiro de Custos, 15.

Romão, E., \& Castellar, M. (2008). Relatório anual de empresa de auditoria mostra que há mais problemas do que soluções na vida financeira das agremiações brasileiras. São Paulo: Lance.

Rondinelli, P. (2015). Futebol: Histórias e curiosidades sobre o futebol. Recuperado de http://www.brasilescola.com/educacao-fisica/futebol.htm

Russano, A., \& Marino, J., Jr. (2007). Contabilidade e Auditoria aplicadas às entidades esportivas: Um estudo sobre os clubes de futebol no Brasil. Revista Brasileira de Contabilidade, (164), 52-65.

Sherry, E., Shilbury, D., \& Wood, G. (2007). Wrestling with "conflict of interest" in sport management. Corporate Governance: The international journal of business in society, 7(3), 267-277.

Silva, T. B. J., Santos, C. A. D., \& Cunha, P. R. (2017). Relação entre o Desempenho Econômico-Financeiro e o Relatório de Auditoria dos Clubes de Futebol Brasileiros. Revista de Gestão, Finanças e Contabilidade, 7(3), 177-200. 
Souza, A., Sousa, W., Nascimento, J., \& Bernardes, J. (2016). Disclosure em Demonstrações Financeiras: Um Estudo Sobre o Nível de Evidenciação Contábil de Clubes de Futebol brasileiros. PODIUM Sport, Leisure And Tourism Review, 5(3), 1-19.

Umbelino, W. L., Silva, R. B., Ponte, V. M. R., \& Lima, M. C. (2019). Disclosure em Clubes de Futebol: Estudo sobre os Reflexos da Lei do PROFUT. Revista Evidenciação Contábil \& Finanças, 7(1), 112-132. doi:10.22478/ufpb.2318-1001.2019v7n1.38074

Verrecchia, R. E. (1983). Discretionary disclosure. Journal of accounting and economics, 5, 179-194.

Zanotelli, E. J., Amaral, H. F., \& Souza, A. A. (2013, Julho). Os ativos intangíveis e a crise de representação contábil. Anais do Congresso USP de Controladoria e Contabilidade, 13.

\section{Como citar este artigo:}

\section{ABNT}

PACHECO, Juliane; SOUZA, Maíra Melo de. Associação entre o nível de evidenciação dos ativos intangíveis e o desempenho econômico-financeiro dos clubes de futebol brasileiros.

RACE, Revista de Administração, Contabilidade e Economia, Joaçaba: Editora Unoesc, v. 18, n. 3, p. 447-474, set./dez. 2019. Disponível em: http://editora.unoesc.edu.br/index.php/ race. Acesso em: dia/mês/ano.

\section{APA}

Pacheco, J., \& Souza, M. M. de (2019). Associação entre o nível de evidenciação dos ativos intangíveis e o desempenho econômico-financeiro dos clubes de futebol brasileiros. RACE, Revista de Administração, Contabilidade e Economia, 18(3), 447-474. Recuperado de http://editora.unoesc.edu.br/index.php/race 